\title{
Programmed Erythrocyte Death Following in Vitro Treosulfan Treatment
}

\author{
Thomas Peter ${ }^{\mathrm{a}}$ Rosi Bissinger ${ }^{\mathrm{a}} \quad$ Sigrid Enkel $^{\mathrm{b}}$ Kousi Alzoubia Gergely Oswald ${ }^{\mathrm{a}}$ \\ Florian Langa
}

Department of Physiology and Blood Transfusion ${ }^{b}$, University of Tübingen, Tübingen, Germany

\author{
Key Words \\ Phosphatidylserine $\bullet$ Reactive oxidant species $•$ Calcium $\bullet$ Cell volume $・$ Eryptosis
}

\begin{abstract}
Background/Aims: The cytotoxic drug Treosulfan is clinically used for the treatment of malignancy. A common side effect of Treosulfan treatment is anemia. Treosulfan is at least partially effective by triggering apoptosis of tumor cells. Similar to apoptosis of nucleated cells, erythrocytes may enter eryptosis, a suicidal death characterized by cell shrinkage and translocation of phosphatidylserine from the inner to the outer leaflet of the plasma membrane. Triggers of eryptosis include oxidative stress, $\mathrm{Ca}^{2+}$-entry and increase of cytosolic $\mathrm{Ca}^{2+}$-activity $\left(\left[\mathrm{Ca}^{2+}\right]_{i}\right)$. The present study explored whether Treosulfan stimulates eryptosis, which may contribute to development of anemia. Methods: Erythrocyte volume was estimated from forward scatter, phosphatidylserine abundance at the erythrocyte surface from Fluorescein isothiocyanate (FITC)-annexin-V-binding, $\left[\mathrm{Ca}^{2+}\right]_{i}$ from Fluo3 fluorescence and reactive oxygen species (ROS) from 2', $7^{\prime}$-dichlorodihydrofluorescein diacetate (DCFDA)fluorescence. Results: A 48 hours exposure of human erythrocytes to Treosulfan $(800 \mu \mathrm{g} /$ $\mathrm{ml}$ ) significantly decreased erythrocyte forward scatter, increased the percentage of annexin$V$-binding cells, increased $\left[\mathrm{Ca}^{2+}\right]_{i^{\prime}}$ and increased ROS. The effect of Treosulfan on annexinV-binding was virtually abrogated by removal of extracellular $\mathrm{Ca}^{2+}$. Conclusion: Treosulfan stimulates suicidal erythrocyte death or eryptosis at least in part by inducing oxidative stress and stimulating $\mathrm{Ca}^{2+}$ entry.

Copyright (C) 2015 S. Karger AG, Basel
\end{abstract}

\section{Introduction}

Treosulfan, a hydrophilic analogue of busulfan [1], is in clinical use for the treatment of ovarian cancer and of hematologic malignancies [1]. The substance is at least in part effective by triggering apoptosis [2-9]. The most common side effect of Treosulfan treatment is anemia, affecting as many as $88 \%$ of the patients [10].

Prof. Dr. Florian Lang

KARGER 125
Physiologisches Institut der Universität Tübingen,

Gmelinstr. 5, D-72076 Tübingen (Germany)

Tel. +49 707129 72194, Fax +49 707129 5618, E-Mail florian.lang@uni-tuebingen.de 
We hypothesized that the anemia following Treosulfan treatment could in part result from accelerated loss of erythrocytes due to stimulation of apoptosis-like suicidal cell death or eryptosis, which is characterized by cell shrinkage [11] and by translocation of phosphatidylserine from the inner to the outer leaflet of the plasma membrane [12].

Signaling participating in the triggering of eryptosis includes oxidative stress [12] and increase of cytosolic $\mathrm{Ca}^{2+}$ activity $\left(\left[\mathrm{Ca}^{2+]}\right)\right.$ [12]. Eryptosis is further triggered by ceramide [13], energy depletion [12], caspase activation [14-17], activation of casein kinase $1 \alpha$ [18, 19], Janus-activated kinase JAK3 [20], protein kinase C [21] or p38 kinase [22], as well as inhibition or knockout of AMP-activated kinase AMPK [23], cGMP-dependent protein kinase [15], PAK2 kinase [24], as well as sorafenib- and sunitinib-sensitive kinases [25, 26].

Eryptosis is triggered by a myriad of xenobiotics [27-63] and enhanced eryptosis contributes to the pathophysiology of several clinical conditions including fever, malaria, sepsis, iron deficiency, malignancy, metabolic syndrome, diabetes, hepatic and renal insufficiency, hemolytic uremic syndrome, dehydration, hyperphosphatemia, phosphate depletion, sickle cell disease, thalassemia, glucose phosphate dehydrogenase deficiency and Wilson's disease [12, 63-65].

The present study tested, whether Treosulfan triggers eryptosis. To this end, erythrocytes drawn from healthy volunteers were exposed to Treosulfan and phosphatidylserine surface abundance, cell volume, $\left[\mathrm{Ca}^{2+}\right]_{\mathrm{i}}$ and reactive oxygen species were determined.

\section{Materials and Methods}

\section{Erythrocytes, solutions and chemicals}

Fresh Lithium-Heparin-anticoagulated blood samples were kindly provided by the blood bank of the University of Tübingen. The study is approved by the ethics committee of the University of Tübingen $(184 / 2003 \mathrm{~V})$. The blood was centrifuged at $120 \mathrm{~g}$ for $20 \mathrm{~min}$ at room temperature and the platelets and leukocytes-containing supernatant was disposed. Erythrocytes were incubated in vitro at a hematocrit of $0.4 \%$ in Ringer solution containing (in mM) $125 \mathrm{NaCl}, 5 \mathrm{KCl}, 1 \mathrm{MgSO}_{4}, 32 \mathrm{~N}$-2-hydroxyethylpiperazine- $\mathrm{N}-2$ ethanesulfonic acid (HEPES), 5 glucose, $1 \mathrm{CaCl}_{2} ; \mathrm{pH} 7.4$ at $37^{\circ} \mathrm{C}$ for $48 \mathrm{~h}$. Where indicated, erythrocytes were exposed to Treosulfan (DocMorris, Aachen, Germany) at the indicated concentrations by dilution of a 200 $\mathrm{mg} / \mathrm{ml}$ stock solution prepared in DMSO. For comparison, the effect of $4 \mu \mathrm{l}$ DMSO/ml Ringer was tested.

\section{Analysis of annexin-V-binding and forward scatter}

After incubation under the respective experimental condition, $150 \mu \mathrm{l}$ cell suspension was washed in Ringer solution containing $5 \mathrm{mM} \mathrm{CaCl}_{2}$ and then stained with Annexin-V-FITC (1:200 dilution; ImmunoTools, Friesoythe, Germany) in this solution at $37^{\circ} \mathrm{C}$ for $15 \mathrm{~min}$ under protection from light. The cell suspension was measured on a FACS Calibur (BD, Heidelberg, Germany). A dot plot of forward scatter (FSC) vs. side scatter (SSC) was set to linear scale for both parameters. A FSC vs. counts histogram plot was established, small particles cut off to eliminate cell debris, and the geomean value of fluorescence intensity calculated. Annexin binding was measured with an excitation wavelength of $488 \mathrm{~nm}$ and an emission wavelength of 530 $\mathrm{nm}$. A marker (M1) was placed to set an arbitrary threshold between annexin-V-binding cells and control cells. The same threshold was used for untreated and treosulfan treated erythrocytes.

\section{Measurement of intracellular $\mathrm{Ca}^{2+}$}

After incubation, erythrocytes were washed in Ringer solution and then loaded with Fluo-3/AM (Biotium, Hayward, USA) in Ringer solution containing $5 \mathrm{mM} \mathrm{CaCl}_{2}$ and $5 \mu \mathrm{M}$ Fluo-3/AM. The cells were incubated at $37^{\circ} \mathrm{C}$ for $30 \mathrm{~min}$ and washed twice in Ringer solution containing $5 \mathrm{mM} \mathrm{CaCl}$. The Fluo-3/AMloaded erythrocytes were resuspended in $150 \mu \mathrm{l}$ Ringer. Then, $\mathrm{Ca}^{2+}$ dependent fluorescence intensity was measured in FL-1 with an excitation wavelength of $488 \mathrm{~nm}$ and an emission wavelength of $530 \mathrm{~nm}$ on a FACS Calibur and the geomean of the $\mathrm{Ca}^{2+-}$ dependent fluorescence was determined.

Quantification of reactive oxidant species (ROS)

Oxidative stress was determined utilizing 2',7'-dichlorodihydrofluorescein diacetate (DCFDA). After incubation, a $150 \mu \mathrm{l}$ suspension of erythrocytes was washed in Ringer solution and then stained with DCFDA 
(Sigma, Schnelldorf, Germany) in Ringer solution containing DCFDA at a final concentration of $10 \mu \mathrm{M}$. Erythrocytes were incubated at $37^{\circ} \mathrm{C}$ for $30 \mathrm{~min}$ in the dark and then washed three times in Ringer solution. The DCFDA-loaded erythrocytes were resuspended in $200 \mu$ l Ringer solution, ROS-dependent fluorescence intensity was measured in FL-1 at an excitation wavelength of $488 \mathrm{~nm}$ and an emission wavelength of 530 $\mathrm{nm}$ on a FACS Calibur (BD) and the geomean of the ROS-dependent fluorescence was determined.

\section{Statistics}

Data are expressed as arithmetic means \pm SEM. The number of experiments (n) denotes the number of blood donors tested. As indicated in the figure legends, statistical analysis was made using ANOVA with Tukey's test as post-test and $t$ test as appropriate. $\mathrm{n}$ denotes the number of different erythrocyte specimens studied.

\section{Results}

The present study explored whether Treosulfan triggers eryptosis, the suicidal erythrocyte death characterized by cell shrinkage and translocation of phosphatidylserine to the erythrocyte surface. To this end, erythrocytes drawn from healthy individuals were incubated for 48 hours in Ringer solution without or with Treosulfan $(100-800 \mu \mathrm{g} / \mathrm{ml})$.

In order to estimate cell volume, forward scatter was determined in flow cytometry. As shown in Fig. 1, a 48 hours incubation in Treosulfan-containing Ringer was followed by a decrease of average forward scatter, an effect reaching statistical significance at $800 \mu \mathrm{g} /$ $\mathrm{ml}$ Treosulfan concentration. Close inspection of the histogram reveals, however, that a large portion of cells actually increases forward scatter (Fig. 1A).

FITC-annexin-V binding was utilized to quantify phosphatidylserine abundance at the erythrocyte surface. As shown in Fig. 2, 48 hours exposure to Treosulfan was followed by an increase of the percentage of annexin-V-binding erythrocytes, an effect reaching statistical significance at $800 \mu \mathrm{g} / \mathrm{ml}$ Treosulfan concentration.

Stimulators of cell shrinkage and cell membrane scrambling with phosphatidylserine translocation to the cell surface include increase of cytosolic $\mathrm{Ca}^{2+}$ activity $\left(\left[\mathrm{Ca}^{2+}\right]_{\mathrm{i}}\right)$. Accordingly, further experiments addressed the effect of Treosulfan on $\left[\mathrm{Ca}^{2+}\right]_{\mathrm{i}^{*}}$ To this end, erythrocytes were loaded with Fluo3-AM and the Fluo3 fluorescence quantified by flow cytometry. Measurements were made following 48 hours incubation in Ringer solution without or with Treosulfan (100 - $800 \mu \mathrm{g} / \mathrm{ml})$. As shown in Fig. 3, exposure of the erythrocytes to Treosulfan

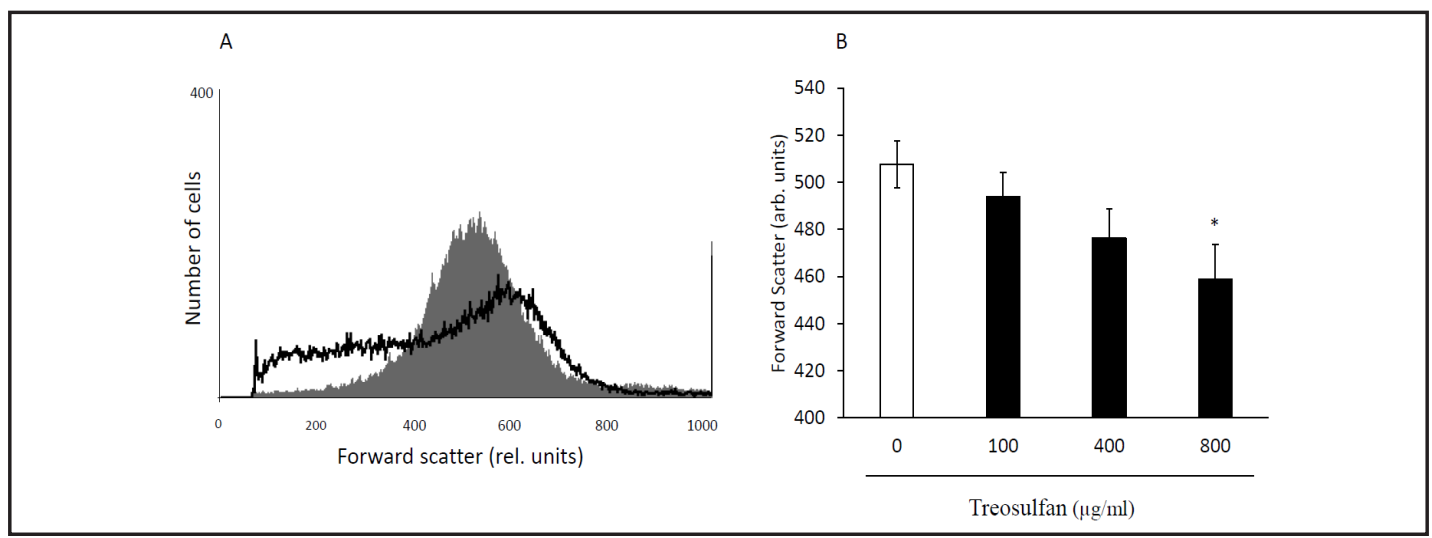

Fig. 1. Effect of Treosulfan on erythrocyte forward scatter. A. Original histogram of forward scatter of erythrocytes following exposure for 48 hours to Ringer solution without (grey area) and with (black line) presence of $800 \mu \mathrm{g} / \mathrm{ml}$ Treosulfan. B. Arithmetic means \pm SEM $(n=17)$ of the erythrocyte forward scatter (FSC) following incubation for 48 hours to Ringer solution without ( $4 \mu \mathrm{l}$ DMSO/ ml Ringer alone, white bar) or with (black bars) Treosulfan $(100-800 \mu \mathrm{g} / \mathrm{ml}) *^{*}(\mathrm{p}<0.05)$ indicates significant difference from the absence of Treosulfan [presence of DMSO alone] (ANOVA). 


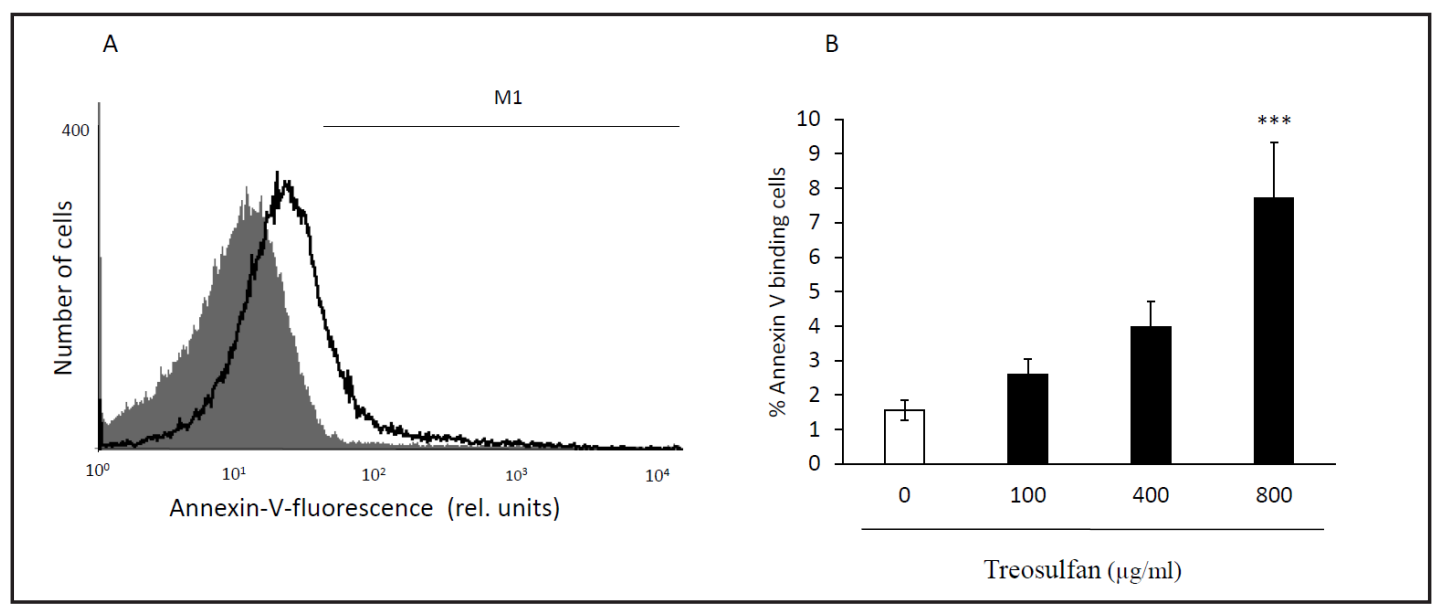

Fig. 2. Effect of Treosulfan on phosphatidylserine exposure. A. Original histogram of annexin-V-binding of erythrocytes following exposure for 48 hours to Ringer solution without (grey area) and with (black line) presence of $800 \mu \mathrm{g} / \mathrm{ml}$ Treosulfan. M1 indicates the annexin-V-fluoresence defining the percentage of annexin-V-binding erythrocytes. B. Arithmetic means \pm SEM $(n=17)$ of erythrocyte annexin-V-binding following incubation for 48 hours to Ringer solution without ( $4 \mu \mathrm{DMSO} / \mathrm{ml}$ Ringer alone, white bar) or with (black bars) presence of Treosulfan $(100-800 \mu \mathrm{g} / \mathrm{ml}) .{ }^{* *}(\mathrm{p}<0.001)$ indicates significant difference from the absence of Treosulfan [presence of DMSO alone] (ANOVA).

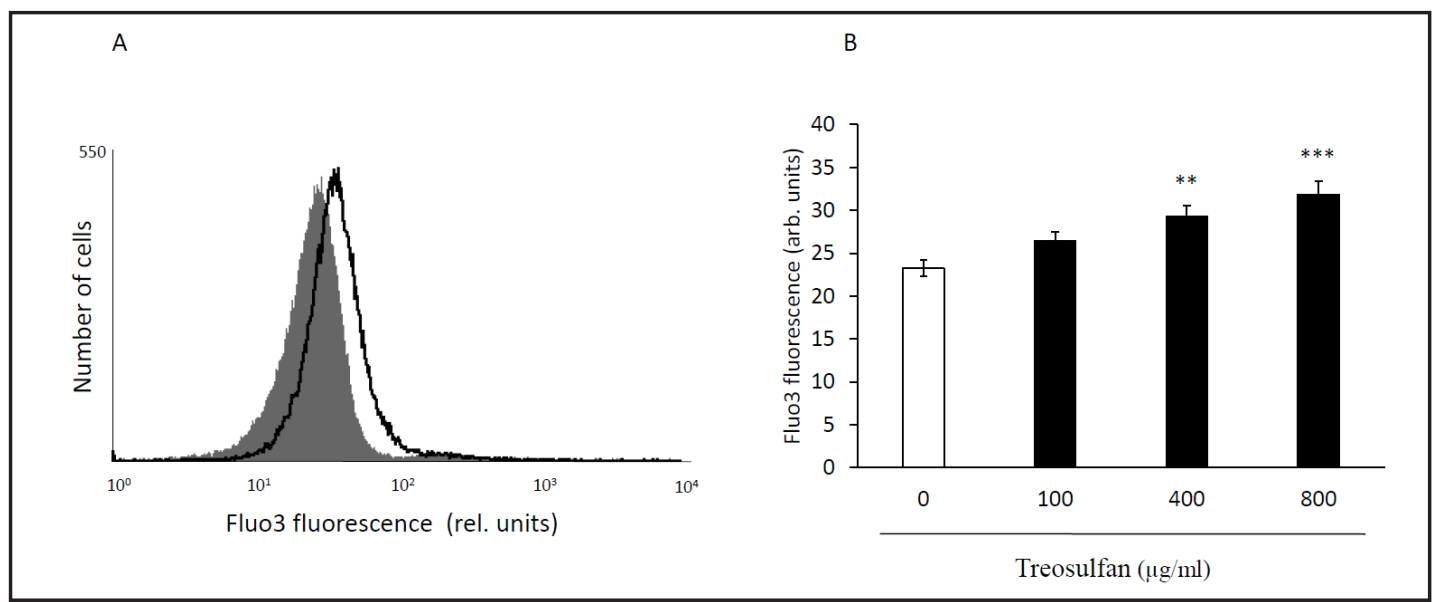

Fig. 3. Effect of Treosulfan on erythrocyte $\mathrm{Ca}^{2+}$ activity. A. Original histogram of Fluo3 fluorescence in erythrocytes following exposure for 48 hours to Ringer solution without (grey area) and with (black line) presence of $800 \mu \mathrm{g} / \mathrm{ml}$ Treosulfan. B. Arithmetic means \pm SEM ( $=17$ ) of the Fluo3 fluorescence (arbitrary units) in erythrocytes exposed for 48 hours to Ringer solution without ( $4 \mu \mathrm{l}$ DMSO/ml Ringer alone, white bar) or with (black bars) presence of Treosulfan $(100-800 \mu \mathrm{g} / \mathrm{ml}) .{ }^{* *}(\mathrm{p}<0.01),{ }^{* * *}(\mathrm{p}<0.001)$ indicate significant differences from the absence of Treosulfan [presence of DMSO alone] (ANOVA).

was followed by an increase of Fluo3 fluorescence, an effect reaching statistical significance at $400 \mu \mathrm{g} / \mathrm{ml}$ Treosulfan concentration.

In order to test whether the Treosulfan-induced cell membrane scrambling required entry of extracellular $\mathrm{Ca}^{2+}$, erythrocytes were exposed to $800 \mu \mathrm{g} / \mathrm{ml}$ Treosulfan for 48 hours either in the presence of $1 \mathrm{mM} \mathrm{Ca}{ }^{2+}$ or in the absence of $\mathrm{Ca}^{2+}$ and the presence of $\mathrm{Ca}^{2+}$ chelator EGTA (1 mM). As illustrated in Fig. 4, the effect of Treosulfan on annexin-V-binding was significantly decreased in the nominal absence of $\mathrm{Ca}^{2+}$. In the absence of extracellular $\mathrm{Ca}^{2+}$ Treosulfan still tended to increase slightly annexin-V-binding. The effect, however, did not reach statistical significance. 
Fig. 4. Effect of $\mathrm{Ca}^{2+}$ withdrawal on Treosulfan- induced phosphatidylserine exposure. Arithmetic means \pm SEM $(n=10)$ of annexin-Vbinding of erythrocytes after a 48 hours treatment with Ringer solution without (white bar) or with (black bars) $800 \mu \mathrm{g} / \mathrm{ml}$ Treosulfan in the presence (left bars, + Calcium) and absence (right bars, - Calcium) of calcium in the Ringer solution. ${ }^{* *}(p<0.01)$ indicates significant difference from the respective values in the absence of Treosulfan, \#\# ( $<<0.01)$ indicates significant difference from the respective value in the presence of $\mathrm{Ca}^{2+}($ ANOVA).
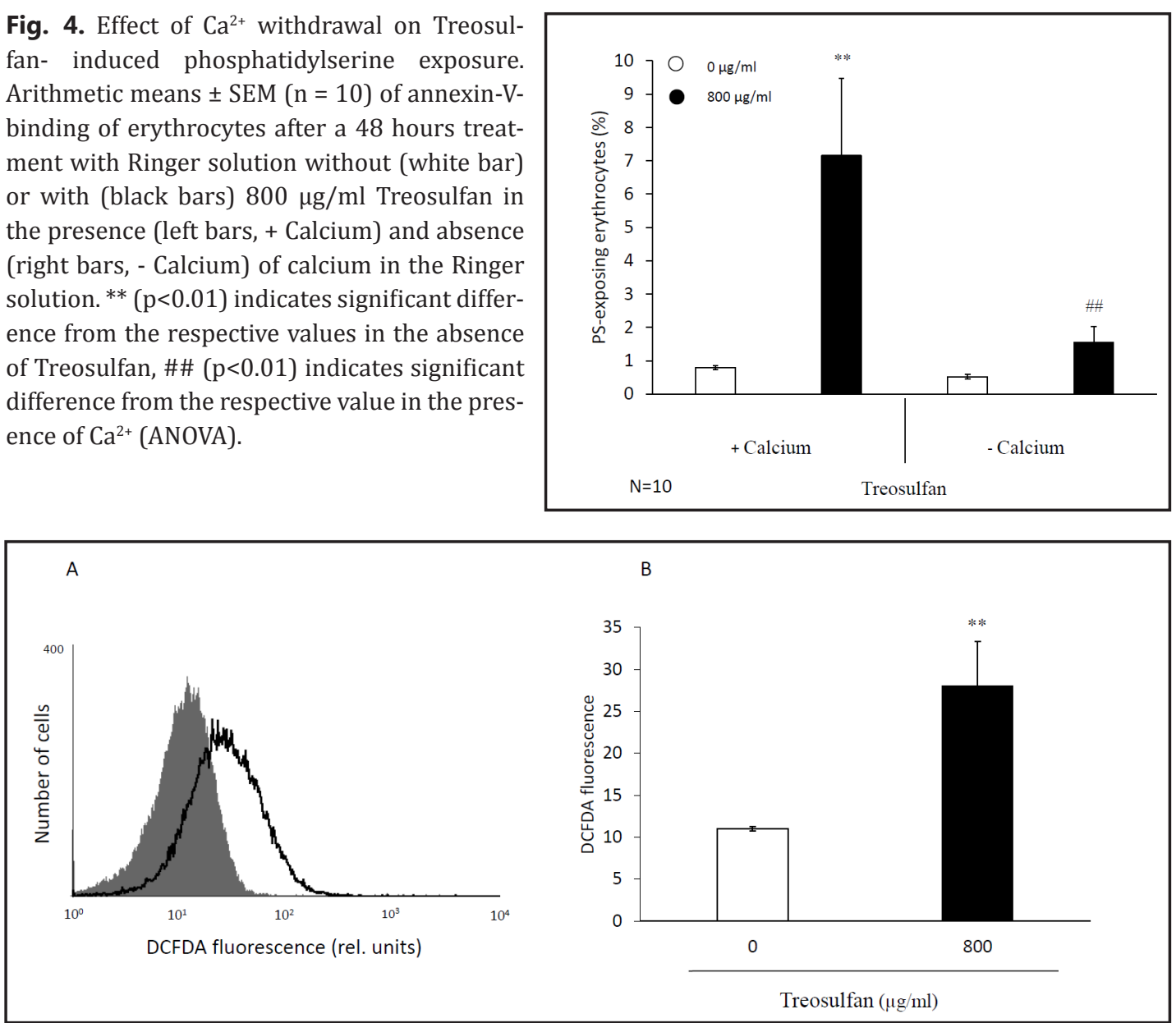

Fig. 5. Effect of Treosulfan on reactive oxygen species. A. Original histogram of $2^{\prime}, 7^{\prime}$-dichlorodihydrofluorescein diacetate (DCFDA) fluorescence in erythrocytes following exposure for 48 hours to Ringer solution without (grey shadow) and with (black line) presence of $800 \mu \mathrm{g} / \mathrm{ml}$ Treosulfan. B. Arithmetic means \pm SEM ( $n=12$ ) of erythrocyte DCFDA fluorescence following incubation for 48 hours to Ringer solution without (white bar) or with (black bar) presence of $800 \mu \mathrm{g} / \mathrm{ml}$ Treosulfan. ${ }^{* *}(\mathrm{p}<0.01)$ indicates significant difference from the absence of Treosulfan ( $t$-test).

$\mathrm{Ca}^{2+}$ entry and eryptosis may be triggered by oxidative stress. In order to test whether Treosulfan increased the abundance of reactive oxygen species (ROS), ROS was determined utilizing 2', $7^{\prime}$-dichlorodihydrofluorescein diacetate (DCFDA). As illustrated in Fig. 5, a 48 hours exposure to Treosulfan $(800 \mu \mathrm{g} / \mathrm{ml})$ significantly increased the DCFDA fluorescence, indicating that Treosulfan triggered oxidative stress.

\section{Discussion}

The present study reveals a novel effect of Treosulfan, i.e. the triggering of eryptosis, the suicidal death of erythrocytes. Treatment of human erythrocytes with Treosulfan is followed by decrease of average erythrocyte volume and by cell membrane scrambling with phosphatidylserine translocation to the erythrocyte surface, both hallmarks of eryptosis [12]. The Treosulfan concentrations $(800 \mu \mathrm{g} / \mathrm{ml})$ required for stimulation of eryptosis was well in the range of those encountered in vivo [66].

The stimulation of cell membrane scrambling and cell shrinkage of erythrocytes following Treosulfan treatment is at least partially due to stimulation of $\mathrm{Ca}^{2+}$ entry with subsequent KARGER 
increase of cytosolic $\mathrm{Ca}^{2+}$ concentration $\left(\left[\mathrm{Ca}^{2+}\right]_{\mathrm{i}}\right)$. Accordingly, removal of extracellular $\mathrm{Ca}^{2+}$ virtually abolished the effect of Treosulfan treatment on phosphatidylserine abundance at the cell surface. The increase of $\left[\mathrm{Ca}^{2+}\right]_{i}$ triggers cell membrane scrambling [12] and is followed by activation of $\mathrm{Ca}^{2+}$ sensitive $\mathrm{K}^{+}$channels, $\mathrm{K}^{+}$exit, hyperpolarization of the cell membrane, $\mathrm{Cl}^{-}$exit and thus cellular loss of $\mathrm{KCl}$ with osmotically obliged water [11]. The increase of $\left[\mathrm{Ca}^{2+}\right]_{\mathrm{i}}$ is presumably due to opening of $\mathrm{Ca}^{2+}$ permeable non-selective cation channels, which are known to be activated by oxidative stress [12]. However, cell shrinkage is seen only in a subset of the erythrocytes and forward scatter actually increases in a large erythrocyte population. The cell swelling may result from entry of $\mathrm{Na}^{+}$through the cation channels.

The stimulation of eryptosis contributes to or even accounts for the anemia observed in the vast majority of patients following Treosulfan treatment [10]. Eryptotic erythrocytes are phagocytosed and rapidly cleared from circulating blood [12]. The development of clinically overt anemia results if the accelerated loss of erythrocytes by eryptosis is not matched by similarly increased formation of new erythrocytes [12]. The formation of new erythrocytes is reflected by the reticulocyte number [12]. The present data do not allow, however, safe predictions about the relative contribution of eryptosis to Treosulfan-induced anemia as compared to other mechanisms, such as Tresulfan-induced inhibition of progenitor cell proliferation.

As erythrocytic phosphatidylserine binds to endothelial CXCL16/SR-PSO [34], eryptotic erythrocytes adhere to the vascular wall and thus interfere with microcirculation [13, 67-71]. Phosphatidylserine exposing erythrocytes further stimulate blood clotting and thrombosis $[67,72,73]$. Thus, excessive stimulation of eryptosis may foster vascular occlusion. Thrombosis has indeed been observed under Treosulfan therapy [74, 75].

In conclusion, Treosulfan treatment leads to erythrocyte shrinkage and cell membrane scrambling with phosphatidylserine translocation to the erythrocyte surface, effects due to oxidative stress and increase of cytosolic $\mathrm{Ca}^{2+}$ activity. The effect presumably contributes to or even accounts for the anemia observed following Treosulfan treatment.

\section{Acknowledgements}

The authors acknowledge the meticulous preparation of the manuscript by Sari Ruebe and Tanja Loch. The study was supported by the Deutsche Forschungsgemeinschaft (Open Access Publishing Fund of Tuebingen University).

\section{References}

1 Galaup A, Paci A: Pharmacology of dimethanesulfonate alkylating agents: busulfan and treosulfan. Expert Opin Drug Metab Toxicol 2013;9:333-347.

2 Meinhardt G, Dayyani F, Jahrsdorfer B, Baumgart J, Emmerich B, Schmidmaier R: Treosulfan is an effective inducer of cell death in myeloma cell lines and primary myeloma cells from patients. Br J Haematol 2003;122:892-899.

3 Munkelt D, Koehl U, Kloess S, Zimmermann SY, Kalaaoui RE, Wehner S, Schwabe D, Lehrnbecher T, Schubert R, Kreuter J, Klingebiel T, Esser R: Cytotoxic effects of treosulfan and busulfan against leukemic cells of pediatric patients. Cancer Chemother Pharmacol 2008;62:821-830.

4 Schmidmaier R, Baumann P, Emmerich B, Meinhardt G: Evaluation of chemosensitivity of human bone marrow stromal cells--differences between common chemotherapeutic drugs. Anticancer Res 2006;26:347-350.

5 Schmidmaier R, Oellerich M, Baumgart J, Emmerich B, Meinhardt G: Treosulfan-induced apoptosis in acute myeloid leukemia cells is accompanied by translocation of protein kinase $\mathrm{C}$ delta and enhanced by bryostatin-1. Exp Hematol 2004;32:76-86.

6 Weissert R, Wiendl H, Pfrommer H, Storch MK, Schreiner B, Barth S, Seifert T, Melms A, Dichgans J, Weller M: Action of treosulfan in myelin-oligodendrocyte-glycoprotein-induced experimental autoimmune encephalomyelitis and human lymphocytes. J Neuroimmunol 2003;144:28-37. 
7 Werner S, Mendoza A, Hilger RA, Erlacher M, Reichardt W, Lissat A, Konanz C, Uhl M, Niemeyer CM, Khanna C, Kontny U: Preclinical studies of treosulfan demonstrate potent activity in Ewing's sarcoma. Cancer Chemother Pharmacol 2008;62:19-31.

8 Wick W, Stock J, Seyfried J, Baumgart J, Wullner U, Weller M: CD95/CD95 ligand-independent potentiation of treosulfan cytotoxicity by BSO in malignant glioma cells in vitro and in vivo. Int J Oncol 2002;21:213220.

9 Wiendl H, Kieseier BC, Weissert R, Mylius HA, Pichlmeier U, Hartung HP, Melms A, Kuker W, Weller M: Treatment of active secondary progressive multiple sclerosis with treosulfan. J Neurol 2007;254:884-889.

10 Mahner S, Oskay-Ozcelik G, Heidrich-Lorsbach E, Fuxius S, Sommer H, Klare P, Belau A, Ruhmland B, Heuser T, Kolbl H, Markmann S, Sehouli J: A prospective multicenter study of treosulfan in elderly patients with recurrent ovarian cancer: results of a planned safety analysis. J Cancer Res Clin Oncol 2012;138:14131419.

11 Lang PA, Kaiser S, Myssina S, Wieder T, Lang F, Huber SM: Role of Ca2+-activated K+ channels in human erythrocyte apoptosis. Am J Physiol Cell Physiol 2003;285:C1553-C1560.

12 Lang E, Qadri SM, Lang F: Killing me softly - suicidal erythrocyte death. Int J Biochem Cell Biol 2012;44:1236-1243.

13 Abed M, Towhid ST, Mia S, Pakladok T, Alesutan I, Borst O, Gawaz M, Gulbins E, Lang F: Sphingomyelinaseinduced adhesion of eryptotic erythrocytes to endothelial cells. Am J Physiol Cell Physiol 2012;303:C991999.

14 Bhavsar SK, Bobbala D, Xuan NT, Foller M, Lang F: Stimulation of suicidal erythrocyte death by alpha-lipoic acid. Cell Physiol Biochem 2010;26:859-868.

15 Foller M, Feil S, Ghoreschi K, Koka S, Gerling A, Thunemann M, Hofmann F, Schuler B, Vogel J, Pichler B, Kasinathan RS, Nicolay JP, Huber SM, Lang F, Feil R: Anemia and splenomegaly in cGKI-deficient mice. Proc Natl Acad Sci USA 2008;105:6771-6776.

16 Lau IP, Chen H, Wang J, Ong HC, Leung KC, Ho HP, Kong SK: In vitro effect of CTAB- and PEG-coated gold nanorods on the induction of eryptosis/erythroptosis in human erythrocytes. Nanotoxicology 2012;6:847856.

17 Maellaro E, Leoncini S, Moretti D, Del Bello B, Tanganelli I, De Felice C, Ciccoli L: Erythrocyte caspase-3 activation and oxidative imbalance in erythrocytes and in plasma of type 2 diabetic patients. Acta Diabetol 2013;50:489-495.

18 Kucherenko Y, Zelenak C, Eberhard M, Qadri SM, Lang F: Effect of casein kinase 1alpha activator pyrvinium pamoate on erythrocyte ion channels. Cell Physiol Biochem 2012;30:407-417.

19 Zelenak C, Eberhard M, Jilani K, Qadri SM, Macek B, Lang F: Protein kinase CK1alpha regulates erythrocyte survival. Cell Physiol Biochem 2012;29:171-180.

20 Bhavsar SK, Gu S, Bobbala D, Lang F: Janus kinase 3 is expressed in erythrocytes, phosphorylated upon energy depletion and involved in the regulation of suicidal erythrocyte death. Cell Physiol Biochem 2011;27:547-556.

21 Klarl BA, Lang PA, Kempe DS, Niemoeller OM, Akel A, Sobiesiak M, Eisele K, Podolski M, Huber SM, Wieder T, Lang F: Protein kinase C mediates erythrocyte "programmed cell death" following glucose depletion. Am J Physiol Cell Physiol 2006;290:C244-C253.

22 Gatidis S, Zelenak C, Fajol A, Lang E, Jilani K, Michael D, Qadri SM, Lang F: p38 MAPK activation and function following osmotic shock of erythrocytes. Cell Physiol Biochem 2011;28:1279-1286.

23 Foller M, Sopjani M, Koka S, Gu S, Mahmud H, Wang K, Floride E, Schleicher E, Schulz E, Munzel T, Lang F: Regulation of erythrocyte survival by AMP-activated protein kinase. FASEB J 2009;23:1072-1080.

24 Zelenak C, Foller M, Velic A, Krug K, Qadri SM, Viollet B, Lang F, Macek B: Proteome analysis of erythrocytes lacking AMP-activated protein kinase reveals a role of PAK2 kinase in eryptosis. J Proteome Res 2011;10:1690-1697.

25 Lupescu A, Jilani K, Zelenak C, Zbidah M, Qadri SM, Lang F: Hexavalent chromium-induced erythrocyte membrane phospholipid asymmetry. Biometals 2012;25:309-318.

26 Shaik N, Lupescu A, Lang F: Sunitinib-sensitive suicidal erythrocyte death. Cell Physiol Biochem 2012;30:512-522.

27 Abed M, Feger M, Alzoubi K, Pakladok T, Frauenfeld L, Geiger C, Towhid ST, Lang F: Sensitization of erythrocytes to suicidal erythrocyte death following water deprivation. Kidney Blood Press Res 2013;37:567-578. 


\begin{tabular}{|c|c|c|}
\hline Cellular Physiology & Cell Physiol Biochem 2015;35:1372-1380 & \\
\hline and Biochemistry & $\begin{array}{l}\text { DOI: } 10.1159 / 000373958 \\
\text { Published online: February 12, } 2015\end{array}$ & $\begin{array}{l}\text { O } 2015 \text { S. Karger AG, Basel } \\
\text { www.karger.com/cpb }\end{array}$ \\
\hline
\end{tabular}

28 Abed M, Zoubi KA, Theurer M, Lang F: Effect of dermaseptin on erythrocytes. Basic Clin Pharmacol Toxicol 2013;113:347-352.

29 Ahmed MS, Langer H, Abed M, Voelkl J, Lang F: The uremic toxin acrolein promotes suicidal erythrocyte death. Kidney Blood Press Res 2013;37:158-167.

30 Alzoubi K, Honisch S, Abed M, Lang F: Triggering of Suicidal Erythrocyte Death by Penta-O-galloyl-beta-dglucose. Toxins (Basel) 2014;6:54-65.

31 Arnold M, Lang E, Modicano P, Bissinger R, Faggio C, Abed M, Lang F: Effect of nitazoxanide on erythrocytes. Basic Clin Pharmacol Toxicol 2014;114:421-426.

32 Bissinger R, Lupescu A, Zelenak C, Jilani K, Lang F: Stimulation of eryptosis by cryptotanshinone. Cell Physiol Biochem 2014;34:432-442.

33 Bissinger R, Malik A, Jilani K, Lang F: Triggering of Erythrocyte Cell Membrane Scrambling by Salinomycin. Basic Clin Pharmacol Toxicol 2014;10.1111/bcpt.12250

34 Borst O, Abed M, Alesutan I, Towhid ST, Qadri SM, Foller M, Gawaz M, Lang F: Dynamic adhesion of eryptotic erythrocytes to endothelial cells via CXCL16/SR-PSOX. Am J Physiol Cell Physiol 2012;302:C644-C651.

35 Bottger E, Multhoff G, Kun JF, Esen M: Plasmodium falciparum-infected erythrocytes induce granzyme B by NK cells through expression of host-Hsp70. PLoS One 2012;7:e33774.

36 Firat U, Kaya S, Cim A, Buyukbayram H, Gokalp O, Dal MS, Tamer MN: Increased caspase-3 immunoreactivity of erythrocytes in STZ diabetic rats. Exp Diabetes Res 2012;2012:316384.

37 Ganesan S, Chaurasiya ND, Sahu R, Walker LA, Tekwani BL: Understanding the mechanisms for metabolism-linked hemolytic toxicity of primaquine against glucose 6-phosphate dehydrogenase deficient human erythrocytes: evaluation of eryptotic pathway. Toxicology 2012;294:54-60.

38 Gao M, Cheung KL, Lau IP, Yu WS, Fung KP, Yu B, Loo JF, Kong SK: Polyphyllin D induces apoptosis in human erythrocytes through $\mathrm{Ca}(2)(+)$ rise and membrane permeabilization. Arch Toxicol 2012;86:741-752.

39 Ghashghaeinia M, Cluitmans JC, Toulany M, Saki M, Koberle M, Lang E, Dreischer P, Biedermann T, Duszenko M, Lang F, Bosman GJ, Wieder T: Age Sensitivity of NFkappaB Abundance and Programmed Cell Death in Erythrocytes Induced by NFkappaB Inhibitors. Cell Physiol Biochem 2013;32:801-813.

40 Jacobi J, Lang E, Bissinger R, Frauenfeld L, Modicano P, Faggio C, Abed M, Lang F: Stimulation of erythrocyte cell membrane scrambling by mitotane. Cell Physiol Biochem 2014;33:1516-1526.

41 Jilani K, Enkel S, Bissinger R, Almilaji A, Abed M, Lang F: Fluoxetine induced suicidal erythrocyte death. Toxins (Basel) 2013;5:1230-1243.

42 Jilani K, Lang F: Carmustine-induced phosphatidylserine translocation in the erythrocyte membrane. Toxins (Basel) 2013;5:703-716.

43 Lang E, Qadri SM, Jilani K, Zelenak C, Lupescu A, Schleicher E, Lang F: Carbon monoxide-sensitive apoptotic death of erythrocytes. Basic Clin Pharmacol Toxicol 2012;111:348-355.

44 Lupescu A, Bissinger R, Herrmann T, Oswald G, Jilani K, Lang F: Induction of suicidal erythrocyte death by novobiocin. Cell Physiol Biochem 2014;33:670-680.

45 Lupescu A, Bissinger R, Jilani K, Lang F: Triggering of suicidal erythrocyte death by celecoxib. Toxins (Basel) 2013;5:1543-1554.

46 Lupescu A, Bissinger R, Warsi J, Jilani K, Lang F: Stimulation of erythrocyte cell membrane scrambling by gedunin. Cell Physiol Biochem 2014;33:1838-1848.

47 Lupescu A, Jilani K, Zbidah M, Lang F: Patulin-induced suicidal erythrocyte death. Cell Physiol Biochem 2013;32:291-299.

48 Oswald G, Alzoubi K, Abed M, Lang F: Stimulation of suicidal erythrocyte death by ribavirin. Basic Clin Pharmacol Toxicol 2014;114:311-317.

49 Polak-Jonkisz D, Purzyc L: Ca Influx versus Efflux during Eryptosis in Uremic Erythrocytes. Blood Purif 2012;34:209-210.

50 Qian EW, Ge DT, Kong SK: Salidroside protects human erythrocytes against hydrogen peroxide-induced apoptosis. J Nat Prod 2012;75:531-537.

51 Tesoriere L, Attanzio A, Allegra M, Cilla A, Gentile C, Livrea MA: Oxysterol mixture in hypercholesterolemiarelevant proportion causes oxidative stress-dependent eryptosis. Cell Physiol Biochem 2014;34:10751089.

52 Vota DM, Maltaneri RE, Wenker SD, Nesse AB, Vittori DC: Differential erythropoietin action upon cells induced to eryptosis by different agents. Cell Biochem Biophys 2013;65:145-157.

53 Weiss E, Cytlak UM, Rees DC, Osei A, Gibson JS: Deoxygenation-induced and $\mathrm{Ca}(2+)$ dependent 


\begin{tabular}{|c|c|c|}
\hline Cellular Physiology & Cell Physiol Biochem 2015;35:1372-138c & \\
\hline and Biochemistry & $\begin{array}{l}\text { DoI: 10.1159/000373958 } \\
\text { Published online: February 12, } 2015\end{array}$ & $\begin{array}{l}\text { O } 2015 \text { S. Karger AG, Basel } \\
\text { www.karger.com/cpb }\end{array}$ \\
\hline
\end{tabular}

phosphatidylserine externalisation in red blood cells from normal individuals and sickle cell patients. Cell Calcium 2012;51:51-56.

54 Zbidah M, Lupescu A, Jilani K, Lang F: Stimulation of suicidal erythrocyte death by fumagillin. Basic Clin Pharmacol Toxicol 2013;112:346-351.

55 Abed M, Herrmann T, Alzoubi K, Pakladok T, Lang F: Tannic acid induced suicidal erythrocyte death. Cell Physiol Biochem 2013;32:1106-1116.

56 Bissinger R, Modicano P, Frauenfeld L, Lang E, Jacobi J, Faggio C, Lang F: Estramustine-induced suicidal erythrocyte death. Cell Physiol Biochem 2013;32:1426-1436.

57 Jilani K, Qadri SM, Lang F: Geldanamycin-induced phosphatidylserine translocation in the erythrocyte membrane. Cell Physiol Biochem 2013;32:1600-1609.

58 Zhang R, Xiang Y, Ran Q, Deng X, Xiao Y, Xiang L, Li Z: Involvement of Calcium, Reactive Oxygen Species, and ATP in Hexavalent Chromium-Induced Damage in Red Blood Cells. Cell Physiol Biochem 2014;34:17801791.

59 Malik A, Bissinger R, Calabro S, Faggio C, Jilani K, Lang F: Aristolochic Acid induced suicidal erythrocyte death. Kidney Blood Press Res 2014;39:408-419.

60 Arnold M, Bissinger R, Lang F: Mitoxantrone-induced suicidal erythrocyte death. Cell Physiol Biochem 2014;34:1756-1767.

61 Alzoubi K, Calabro S, Bissinger R, Abed M, Faggio C, Lang F: Stimulation of suicidal erythrocyte death by artesunate. Cell Physiol Biochem 2014;34:2232-2244.

62 Bissinger R, Fischer S, Jilani K, Lang F: Stimulation of erythrocyte death by phloretin. Cell Physiol Biochem 2014;34:2256-2265.

63 Voelkl J, Alzoubi K, Mamar AK, Ahmed MS, Abed M, Lang F: Stimulation of suicidal erythrocyte death by increased extracellular phosphate concentrations. Kidney Blood Press Res 2013;38:42-51.

64 Abed M, Artunc F, Alzoubi K, Honisch S, Baumann D, Foller M, Lang F: Suicidal erythrocyte death in endstage renal disease. J Mol Med (Berl) 2014;92:871-879.

65 Lang E, Gatidis S, Freise NF, Bock H, Kubitz R, Lauermann C, Orth HM, Klindt C, Schuier M, Keitel V, Reich M, Liu G, Schmidt S, Xu HC, Qadri SM, Herebian D, Pandyra AA, Mayatepek E, Gulbins E, Lang F, Haussinger D, Lang KS, Foller M, Lang PA: Conjugated bilirubin triggers anemia by inducing erythrocyte death. Hepatology 2014;10.1002/hep.27338

66 Scheulen ME, Hilger RA, Oberhoff C, Casper J, Freund M, Josten KM, Bornhauser M, Ehninger G, Berdel WE, Baumgart J, Harstrick A, Bojko P, Wolf HH, Schindler AE, Seeber S: Clinical phase I dose escalation and pharmacokinetic study of high-dose chemotherapy with treosulfan and autologous peripheral blood stem cell transplantation in patients with advanced malignancies. Clin Cancer Res 2000;6:4209-4216.

67 Andrews DA, Low PS: Role of red blood cells in thrombosis. Curr Opin Hematol 1999;6:76-82.

68 Closse C, Dachary-Prigent J, Boisseau MR: Phosphatidylserine-related adhesion of human erythrocytes to vascular endothelium. Br J Haematol 1999;107:300-302.

69 Gallagher PG, Chang SH, Rettig MP, Neely JE, Hillery CA, Smith BD, Low PS: Altered erythrocyte endothelial adherence and membrane phospholipid asymmetry in hereditary hydrocytosis. Blood 2003;101:46254627.

70 Pandolfi A, Di Pietro N, Sirolli V, Giardinelli A, Di Silvestre S, Amoroso L, Di Tomo P, Capani F, Consoli A, Bonomini M: Mechanisms of uremic erythrocyte-induced adhesion of human monocytes to cultured endothelial cells. J Cell Physiol 2007;213:699-709.

71 Wood BL, Gibson DF, Tait JF: Increased erythrocyte phosphatidylserine exposure in sickle cell disease: flowcytometric measurement and clinical associations. Blood 1996;88:1873-1880.

72 Chung SM, Bae ON, Lim KM, Noh JY, Lee MY, Jung YS, Chung JH: Lysophosphatidic acid induces thrombogenic activity through phosphatidylserine exposure and procoagulant microvesicle generation in human erythrocytes. Arterioscler Thromb Vasc Biol 2007;27:414-421.

73 Zwaal RF, Comfurius P, Bevers EM: Surface exposure of phosphatidylserine in pathological cells. Cell Mol Life Sci 2005;62:971-988.

74 Sunderkotter C, Eickelmann M, Kohler M, Schmittel A, Wacker FK: Remission of extensive intrahepatic metastasis by $\mathrm{C}$-arm computed tomography guided chemoembolization in uveal melanoma. J Dtsch Dermatol Ges 2010;8:525-528.

75 Wick W, Hermisson M, Kortmann RD, Kuker WM, Duffner F, Dichgans J, Bamberg M, Weller M: Neoadjuvant gemcitabine/treosulfan chemotherapy for newly diagnosed glioblastoma: a phase II study. J Neurooncol 2002;59:151-155. 